\title{
Modified Lyon brace: with antero-lateral pressure to allow Kyphosis
}

\author{
G Notin $^{1 *}$, L Journoud ${ }^{1}$, J Deceuninck ${ }^{2}$, C Lecante ${ }^{2}$, F Barral $^{1}$, JC Bernard ${ }^{2}$ \\ From 9th International Conference on Conservative Management of Spinal Deformities - SOSORT 2012 \\ Annual Meeting \\ Milan, Italy. 10-12 May 2012
}

\section{Background}

In the 50's, Pierre Stagnara introduced the "lyon treatment ». It included an Abbott plaster cast, followed by a Lyon brace.

\section{Aim}

Can 3D analysis help us today?

\section{Methods}

Lyon braces are designed as Abbott plaster casts. Using a study on plaster cast, and 3D analysis, (called " is Abbot cast still relevant today? » by Dr. Jean Claude Bernard, from the Massues center in Lyon, presented at the SOSORT 2011), we decided to modify a Lyon brace. If a plaster cast is modified, in order to improve sagittal plane by inverting band, and so having antero lateral push in the thoracic part, instead of a classical postero lateral push, the design of the Lyon brace used for the same patient will have an antero lateral pad too.

\section{Results}

The improvement of sagittal plane shown is maintained with the modified Lyon brace

\section{Conclusion}

Introducing 3D analysis, in the design of braces, seems as relevant to maintain sagittal plane as shown last year for plaster cast.

\section{Author details}

'Lecante company ,Lyon, France. ${ }^{2}$ Croix Rouge française CMCR Les Massues, Lyon, France.

Published: 3 June 2013

'Lecante company ,Lyon, France

Full list of author information is available at the end of the article

\section{Reference}

- Berthonnaud E, Dimnet J, Hilmi R: Classification of pelvic and spinal postural patterns in upright position. Specific cases of scoliotic patients. Comput Med Imaging Graph 2009, 33(8):634-643.

doi:10.1186/1748-7161-8-S1-P15

Cite this article as: Notin et al: Modified Lyon brace: with antero-lateral pressure to allow Kyphosis. Scoliosis 2013 8(Suppl 1):P15.
Submit your next manuscript to BioMed Central and take full advantage of:

- Convenient online submission

- Thorough peer review

- No space constraints or color figure charges

- Immediate publication on acceptance

- Inclusion in PubMed, CAS, Scopus and Google Scholar

- Research which is freely available for redistribution

Submit your manuscript at www.biomedcentral.com/submit 